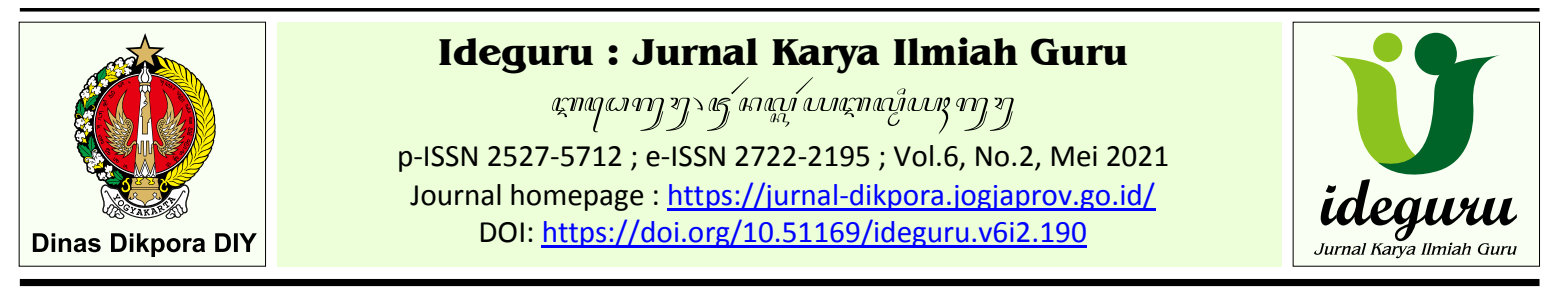

Artikel Penelitian - Naskah dikirim: 31/12/2020 - Selesai revisi: 27/03/2021 - Disetujui: 28/03/2021 - Diterbitkan: 01/05/2021

\title{
Peningkatan Motivasi Melaksanakan Penelitian Tindakan Kelas bagi Guru Matematika SMK melalui Workshop
}

\author{
Giyarsih \\ Balai Pendidikan Menengah Kabupaten Kulon Progo \\ asih125@yahoo.co.id
}

\begin{abstract}
Abstrak: Tujuan penelitian ini untuk meningkatkan motivasi guru dalam melaksanakan kegiatan penelitian tindakan kelas (PTK) melalui workshop agar guru semakin profesional, sehingga proses belajar mengajar menjadi lancar dan prestasi belajar siswa meningkat. Setelah mengetahui permasalahan ini, pengawas dapat mengoptimalisasi kompetensi guru melalui workshop bagi guru Matematika SMK Kabupaten Kulon Progo. Metode penelitian menggunakan Penelitian Tindakan Sekolah (PTS). Subyek penelitian adalah guru matematika binaan yang membutuhkan pendampingan intensif, pada tiga sekolah binaan di kabupaten Kulon Progo. Hasil penelitian yang diperoleh dari delapan guru binaan dapat disimpulkan bahwa workshop dan pembimbingan dapat meningkatkan pengetahuan guru tentang pengembangan profesi; meningkatkan motivasi guru untuk melakukan kegiatan pengembangan profesi; meningkatkan motivasi guru untuk menulis PTK; meningkatkan aktivitas menulis bagi peserta workshop dan dapat meningkatkan profesionalisme guru.
\end{abstract}

Kata Kunci: motivasi guru, penelitian tindakan kelas, workshop

\section{Improvement of Motivation to Perform the Classroom Action Research for Vocational High School Mathematics Teachers through Workshop}

\begin{abstract}
The purpose of the research is to increase teacher motivation in carrying out classroom activities research (PTK) through training, so that teachers are more professional, the teaching and learning process becomes smooth and student learning achievement increases. Based on this condition, the supervisor can optimize teacher competence through a workshop not only in professional but also on pedagogic, and give guidance for the math teachers in Kulon Progo regency. The research method used is the School Action Research (PTS). The research subjects are based on priority scale of math teachers who need guidance intensively. The subjects of the research are Math teachers from three target schools in Kulon Progo regency which are active join in the workshop and guidance. From the research result obtained from eight mentored teachers it can be argued that workshop and guidance can up grade teacher's knowledge about the professionals profession; increase teacher motivation to write class action research: improve written activities for workshop participants, and intensify teacher professionalism.
\end{abstract}

Keywords: teacher motivation, classroom activities research, workshop

\section{Pendahuluan}

Masih dijumpai minat guru untuk melakukan kegiatan pengembangan profesi rendah, bimbingan dalam Pengembangan Keprofesian Berkelanjutan (PKB) belum maksimal, pendampingan dalam melaksanakan kegiatan pengembangan profesi masih kurang, banyaknya dan beratnya beban guru. Jumlah guru golongan IV/a yang usul penilaian Angka Kredit (PAK) sebanyak 203, yang lolos ke IV/b hanya satu (Balai Dikmen KP, 2020).

Pengembangan professional guru perlu dilakukan, sebagai upaya untuk meningkatkan mutu guru maupun siswa disamping itu juga untuk mengimbangi pengakuan profesi guru oleh pemerintah. Usaha guru untuk meningkatkan profesionalisme, menunjukkan komitmen dan tanggungjawab yang tinggi merupakan timbal balik atas penghargaan profesi yang sudah diberikan oleh pemerintah. Agar prestasi belajar siswa maksimal, guru harus meningkatan kualitas pembelajaran secara kontinu. Seperti yang disampaikan oleh Mustofa bahwa pemerintah telah berusaha meningkatkan profesonalisme guru melalui MGMP, sikap profesional dan inovatif guru perlu diupayakan pemerintah agar dapat melaksanakan peran dan tugasnya mendidik masyarakat menuju kehidupan yang lebih baik dan berkualitas (Mustofa, 2007: 87). Upaya meningkatkan profesionalisme ditempuh guru dengan jalan mengikuti pendidikan dan pelatihan, untuk memperbaiki pembelajaran di kelas, guru perlu melaksanakan Penelitian Tindakan Kelas ( PTK ). 
Hal tersebut sesuai dengan pendapat Dinisiswani dan Suwarno, yang menyatakan bahwa dengan pelatihan dan pendampingan dapat meningkatkan wawasan dan keterampilan tentang penyusunan proposal, pelaksanaan PTK, dan penyusunan laporan PTK (Suwarno, 2016: 10). Dengan pelatihan dan pendampingan dapat meningkatkan pemahaman guru tentang PTK, hal ini sesuai dengan pendapat Padruljana dan Bayu Pamungkas yang mengatakan bahwa dengan pelatihan dapat meningkatkan pemahaman guru dalam menyusun proposal PTK, melaksanakan penelitian dan membuat pelaporan hasil PTK (Padruljana dan Bayu Pamungkas, 2018: 45).

Beberapa guru di lingkungan Kabupaten Kulon Progo masih ada yang belum melakukan kegiatan PKB, karena pengetahuan guru tentang pengembangan profesi masih kurang dan motivasi guru untuk menulis PTK masih rendah. Guru perlu dimotivasi agar melaksanakan penelitian dan menulisnya dalam bentuk laporan PTK. Keberhasilan dalam mendorong atau memotivasi guru melakukan PTK sudah dilaksankan oleh pengabdi kegiatan IbM dalam penelitiannya Madzuki dan Muhammad Noor Kholid yang menyebutkan bahwa ada 23 guru matematika SMA/SMK dan 5 orang guru matematika SMP Muhammadiyah di Klaten yang mampu melaksanakan kegiatan PTK secara berkelompok dan 20 guru melaksanakan PTK dan penulisan artikel ilmiah (Madzuki dan Kholid, 2017: 126).

Dari data kenaikan pangkat guru di Balai Pendidikan Menengah kabupaten Kulon Progo menunjukkan bahwa tahun 2020 hanya seorang guru golongan IV/a yang lolos ke IV/b. Mereka terkendala pada pengembangan profesi, khususnya penelitian. Dengan meningkatnya golongan ruang guru dari jabatan yang lebih rendah ke golongan yang lebih tinggi, berarti terjadi peningkatan profesionalisme guru. Untuk itulah diperlukan adanya penelitian tentang meningkatkan motivasi guru dalam melaksanakan kegiatan penelitian tindakan kelas (PTK) melalui workshop pada kegiatan MGMP Sekolah Kabupaten Kulon Progo.

Cara terbaik untuk mengembangkan kemampuan guru dalam melakukan dan membuat laporan PTK adalah metode workshop dan pendampingan PTK melalui kegiatan MGMP serta melalui program pendampingan dan supervisi akademis, karena workshop mengandung rasa senang dan ingin tahu. Seperti yang disampaikan dalam penelitian I Gede Astawan yang menyimpulkan bahwa dengan workshop dan pendampingan terjadi peningkatan kemampuan guru-guru SD di Gugus VII Kecamatan Sukasada dalam menulis karya ilmiah penyusunan PTK (I Gede Astawan, 2019: 117).

Menurut Suharsimi Arikunto dalam Dinisiswani dan Suharno, PTK terdiri dari kata penelitian, tindakan, dan kelas. Penelitian adalah kegiatan mencermati objek menggunakan aturan tertentu untuk memperoleh data dan informasi yang bermanfaat dalam meningkatkan mutu. Tindakan adalah kegiatan yang sengaja dilakukan dengan tujuan tertentu, sedangkan kelas adalah sekelompok siswa dalam waktu yang sama menerima pelajaran yang sama dari seorang guru (Dinisiswani dan Suharno, 2016: $3)$.

Menurut Agus Purnomo, workshop adalah kegiatan diskusi dan praktik dalm forum untuk menyelesaikan masalah (Agus Purnomo, 2015: 28). Bertolak dari itu, diharapkan motivasi dan aktivitas peserta workshop dalam meningkatkan profesinya sebagai peneliti semakin meningkat. Dengan demikian, peserta workshop akan merasakan manfaat mengikuti workshop dan pendampingan PTK. Disamping itu dengan adanya program pendampingan melalui supervisi akademis guru diharapkan dapat meningkatkan motivasi dan aktivitas siswa dalam proses pembelajaran sehingga mereka dapat belajar secara enjoy, aktif, kreatif, mandiri, dan mempermudah pemahaman konsep yang ada pada matematika. Dengan demikian, siswa akan merasakan manfaat mempelajari matematika yang konsepnya sering dibutuhkan untuk memecahkan permasalahan yang muncul dalam kehidupan nyata, serta pembelajaran yang disampaikan oleh guru tidak monoton, atau hanya menggunakan metode konvensional. Hal ini diupayakan untuk variasi dalam pembelajaran dan mengurangi kebosanan anak.

Identifikasi masalah yaitu Kurangnya pengetahuan guru tentang penyusunan PTK akan berdampak pada tingkat profesionalisme guru yang rendah dan kurangnya motivasi guru untuk melakukan PTK. Rumusan masalah dalam penelitian ini yaitu; Bagaimana kegiatan workshop dapat meningkatkan motivasi melaksanakan PTK bagi guru Matematika SMK? Sedangkan tujuan penelitian ini adalah untuk mengetahui dan mendeskripsikan peningkatan motivasi melaksanakan PTK bagi guru Matematika SMK melalui kegiatan workshop.

\section{Metode Penelitian}

Jenis penelitian dalam penelitian ini adalah penelitian tindakan sekolah (PTS), subyek penelitian adalah guru Matematika SMK di tiga sekolah binaan kabupaten Kulon Progo, waktu 
penelitian pada semester 2 tahun pelajaran 2016/2017. Tempat penelitian adalah SMK Bopkri Sentolo, SMK Muhammadiyah 1 Lendah, dan SMK N Kokap. Cara pelaksanaannya yaitu: diawali dengan melaksanakan workshop sebanyak tiga kali. Workshop pertama tentang judul PTK, kemudian melakukan pembimbingan guru tentang pembuatan judul PTK, dilanjutkan dengan pemberian kesempatan kepada guru untuk mempresentasikan judul PTK. workshop kedua tentang Proposal PTK, Kemudian melakukan pembimbingan guru tentang pembuatan Proposal PTK, dilanjutkan dengan pemberian kesempatan kepada guru untuk mempresentasikan Proposal PTK. workshop ketiga tentang laporan Hasil PTK, Langkah selanjutnya mendampingi guru dalam melaksanakan PTK. Dalam mendampingi guru dalam melaksanakan PTK, dilakukan diskusi konsultasi sehingga guru dapat menemukan sendiri permasalahannya sampai proses pembelajaran berikutnya semakin baik. Kemudian melakukan pembimbingan guru tentang pembuatan laporan Hasil PTK, dilanjutkan dengan pemberian kesempatan kepada guru untuk mempresentasikan laporan Hasil PTK.

\section{Rencana Penelitian Tindakan}

Rencana PTS yang digunakan sesuai dengan siklus kegiatan PTK dari dirjen PMPTK Depdiknas (Surya Dharma, 2008: 15). Eksplorasi pemahaman peserta tentang PTK melalui pendekatan andragogi.

Penyampaian materi workshop menggunakan pendekatan andragogy, Peserta diminta mengungkapkan kembali pengalaman, menganalisis, meyimpulkan, dan menggeneralisasi dalam suasana workshop yang aktif, inivatif, kreatif, efektif, menyenngkan, dan bermakna ini dimaksudkan untuk mengoptimalkan proses kegiatan workshop bagi guru matematika SMK se kabupaten Kulon Progo.
Peserta memahami materi yang ada pada makalah secara berkelompok kecil dan membahas tugas secara berdiskusi. Hal ini seperti yang diungkapkan Sujarwo bahwa dalam pendekatan andragogi, peserta harus dihargai, pengalaman yang dimiliki peserta dapat dijadikan sumber belajar, pengalaman yang sudah dimiliki dapat dijadikan sumber belajar dan orientasi belajar diarahkan pada upaya pemenuhan kebutuhan (Sujarwo, 2020: 11).

Fasilitator memandu jalannya presentasi setiap peserta sampai semua peserta mempresantikan hasil diskusi dan secara bersama-sama membuat kesimpulan. Untuk mengetahui tingkat pemahaman peserta, fasilitator memberi tugas peserta secara berkelompok untuk membuat judul PTK, hasilnya dipresentasikan ke forum kelas. Kemudian secara bersama-sama menyimpulkan materi workshop tentang judul PTK. Pelaksanaan tindakan ini terdiri dari tiga siklus, siklus satu, dua dan tiga dilakukan dengan cara yang sama, setiap siklus hasilnya dianalisis. Agar kegiatan berikutnya semakin baik perlu dilakukan analisis baik keberhasilan maupun kegagalan tindakan.

Pelaksanaan Penelitian Tindakan Sekolah mencakup empat tahap: 1) Perencanaan. 2) Pelaksanaan Tindakan: Menyajikan materi tentang Penulisan PTK (tiga siklus). 3) Pengamatan Proses Tindakan: Penulis melaksanakan PTS sendiri tanpa kolabolator pengumpulan data dan pengamatan pembelajaran di sekolah. 4) Refleksi, peneliti merefleksi bersama semua peserta yang mengikuti tindakan yang bertempat di ruang sidang. Para peserta dibagikan angket tentang workshop dan pendampingan penulisan PTK. Hasil refleksi dipakai untuk memperbaiki dan menyempurnakan proses tindakan, untuk tahap perencanaan siklus selanjutnya.

Teknik pengumpulan data dalam PTS ini disajikan pada tabel 1 berikut:

Tabel 1 Teknik Pengumpulan Data

\begin{tabular}{lll}
\hline Sumber Data & \multicolumn{1}{c}{ Jenis Data dan Indikator } & Teknik pengumpulan \\
\hline Peserta dikat & $\bullet$ & Motivasi: tingkat kesenangan, semangat \\
& mengerjakan tugas, dan tanggung jawab & $\bullet$ Angket \\
& - Aktivitas: tingkat keceriaan, keseriusan, & \\
& ketekunan dalam mengerjakan tugas, frekuensi & \\
& bertanya/berpendapat, kecepatan respon yang & \\
& timbul, ketepatan permasalahan yang diajukan & \\
& dan kebenaran hasil yang diperoleh & \\
& - Hasil kerja peserta workshop Siklus I & Dokumen \\
& - Hasil kerja peserta workshop Siklus II & \\
& - Hasil kerja peserta workshop Siklus III & \\
\hline
\end{tabular}


Data yang berbentuk angka disajikan menggunakan tabel, ditentukan nilai rataratanya dan dipersentase. Sedangkan untuk data yang tidak berbentuk angka, dianalisis dengan menggunakan metode analisis kualitatif, yaitu dengan mengadakan wawancara atau memadukan hasil pengamatan antara peneliti dengan peserta workshop.

Motivasi menjadi penggerak dari sebagian besar perilaku orang, yang teridiri dari tiga unsur terkait. Yaitu: motivasi dimulai dari adanya perubahan energi dalam pribadi, motivasi ditandai dengan timbulnya perasaan dan motivasi ditandai dengan reaksi untuk mencapai tujuan (Martinis Yamin, 2006: 8).

Dari pendapat di atas, dalam penelitian ini ada empat indikator keberhasilan yaitu: 1) Motivasi dan aktivitas peserta dalam kegiatan workshop dalam penulisan PTK. 2) Nilai tes awalt maupun pos-test. 3) Perasaan senang dan termotivasi peserta yang ditunjukkan oleh Skor/nilai peserta dari hasil angket setelah kegiatan workshop penulisan PTK. 4) Judul PTK, proposal penelitian dan laporan hasil penelitian.

Penelitian dikatakan berhasil, apabila persentase motivasi dan aktivitas peserta yang mencapai 70\% sebanyak 85\%. Disamping itu Penelitian dikatakan berhasil, apabila nilai tes akhir peserta mencapai KKM, yaitu 61 (mencapai ketuntasan perorangan), serta mencapai ketuntasan klasikal yaitu $85 \%$ jumlah peserta workshop memperoleh nilai lebih dari atau sama dengan KKM. Disamping itu dari siklus pertama ke siklus berikutnya peserta termotivasi untuk belajar menulis PTK dan terjadi peningkatan aktivitas menulis.

Hasil analisa data menunjukkan bahwa hasil pengumpulan tugas workshop selalu bertambah dan persentase rekapitulasi hasil observasi selama kegiatan workshop selalu meningkat dari siklus pertama ke siklus berikutnya. Artinya workshop dan pembimbingan penulisan PTK dapat meningkatkan pengetahuan guru tentang pengembangan profesi dan dapat membangkitkan motivasi guru untuk menulis PTK

\section{Hasil dan Pembahasan}

PTS dilaksanakan dalam kegiatan MGMP maupun di kelas sekolah binaan, penelitian ini berusaha meningkatkan motivasi dan aktivitas melakukan penelitian bagi guru matematika SMK maupun memperbaiki proses pembelajaran di sekolah binaan.

PTS dilaksankan dengan tiga siklus, tiap siklus hasilnya dianalisis keberhasilan maupun kegagalan tindakan sebagai bahan pertimbangan dan refleksi untuk perbaikan pembelajaran selanjutnya. Peneliti mengawali tindakan dengan mengamati terhadap aktivitas peserta MGMP Sekolah untuk mengetahui motivasi dan aktivitas peserta.

Setelah siklus ketiga selesai dijalankan, peserta diberi angket model workshop penulisan PTK. Kemudian para peserta workshop dimohon untuk mengumpulkan judul PTK dengan benar, proposal penelitian dengan benar, dan membuat sistematika laporan hasil penelitian dalam bentuk soft-copy maupun hard-copy.

\section{Siklus Pertama}

Pertemuan pertama workshop tentang Judul PTK dilanjutkan dengan pertemuan kedua yaitu peserta mempresentasi judul PTK, dengan langkah-langkah: Rencana: Sesuai dengan Rencana Penyajian; Pelaksanaan: Setiap tindakan (tindakan satu dan dua) dalam melaksanakan workshop dan pembimingan PTK pada kegiatan MGMP serta melalui program pendampingan melalui supervisi akademis;

Pengamatan (Observasi): semua peserta workshop sebagai kolaboran artinya masingmasing peserta bisa saling melakukan pengamatan. Pertemuan Pertama, hasil pengamatan pada siklus pertama, pertemuan pertama menunjukkan bahwa peserta workshop belum terbiasa berani bertanya atau mengemukakan pendapat, jika diberi stimulan responnya masih rendah, peserta workshop yang mengemukakan permasalahan belum tepat, kebenaran hasil yang diperoleh belum tentu benar.

Tabel 2. Hasil Motivasi dan Aktivitas Peserta workshop Pra Siklus, Pertemuan 1 dan 2 Siklus I

\begin{tabular}{cccccccc}
\hline No & \multicolumn{2}{c}{ Kriteria } & \multicolumn{2}{c}{ Pra Siklus } & \multicolumn{2}{c}{$\begin{array}{c}\text { Pertemuan 1 } \\
\text { Siklus I }\end{array}$} & \multicolumn{2}{c}{$\begin{array}{c}\text { Pertemuan 2 } \\
\text { Siklus I }\end{array}$} \\
\cline { 3 - 8 } & & $\begin{array}{c}\text { Jumlah } \\
\text { Peserta }\end{array}$ & $\begin{array}{c}\text { Persen- } \\
\text { tase }\end{array}$ & $\begin{array}{c}\text { Jumlah } \\
\text { Peserta }\end{array}$ & $\begin{array}{c}\text { Persen- } \\
\text { tase }\end{array}$ & $\begin{array}{c}\text { Jumlah } \\
\text { Peserta }\end{array}$ & $\begin{array}{c}\text { Persen- } \\
\text { tase }\end{array}$ \\
\hline 1 & Sangat Tinggi (80-100\%) & 0 & 0 & 0 & 0 & 0 & 0 \\
2 & Tinggi (70-79\%) & 0 & 0 & 1 & 12,5 & 3 & 37,50 \\
3 & Sedang (60-69\%) & 6 & 75 & 6 & 62,55 & 5 & 62,50 \\
4 & Kurang (0-59\%) & 2 & 25 & 1 & 12,50 & 0 & 0 \\
\hline & \multicolumn{1}{c}{ Jumlah } & 8 & 100 & 8 & 100 & 8 & 100 \\
\hline
\end{tabular}


Dari tabel 2 di atas, dapat dideskripsikan bahwa hasil pengamatan pada siklus I, motivasi dan aktivitas peserta dengan kriteria tinggi semakin meningkat yaitu mencapai $37,50 \%$. Walaupun masih ada peserta yang motivasi dan aktivitasnya sedang yaitu sebesar $62,50 \%$. Indikator keberhasilan dalam penelitian ini, sebanyak $85 \%$ peserta memperoleh $70 \%$ untuk motivasi dan aktivitas, berdasarkan tabel 2 belum mencapai $70 \%$, hanya $37,5 \%$ dari keseluruhan peserta. Mengingat target penelitian belum berhasil, maka perlu dilanjutkan dengan siklus kedua.

\section{Siklus kedua}

Rencana pada siklus kedua sesuai dengan Rencana Penyajian. Pada tahap pelaksanaan, setiap tindakan (tindakan satu dan dua) dilakukan workshop dan pendampingan penelitian tindakan kelas dalam kegiatan MGMP serta melalui program pendampingan melalui supervisi akademis. Langkah-langkah pendekatannya sebagai berikut: pertemuan pertama workshop tentang proposal PTK, sedangkan pertemuan kedua presentasi proposal PTK.

Pada tahap pengamatan (observasi) pertemuan pertama siklus kedua, hasil pengamatan menunjukkan bahwa peserta workshop belum terbiasa berani bertanya atau mengemukakan pendapat, jika diberi stimulant responnya masih rendah, peserta workshop yang mengemukakan permasalahan belum tepat, kebenaran hasil yang diperoleh belum tentu benar. Terlihat dari persentase perolehan nilai yang penulis kriteriakan seperti tertera pada tabel 3 berikut.

Tabel 3. Hasil Motivasi dan Aktivitas Peserta workshop pertemuan 1 dan 2 Siklus II

\begin{tabular}{lcccc}
\hline \multirow{1}{*}{ Kriteria } & \multicolumn{2}{c}{$\begin{array}{c}\text { Pertemuan 1 } \\
\text { Siklus II }\end{array}$} & \multicolumn{2}{c}{$\begin{array}{c}\text { Pertemuan 2 } \\
\text { Siklus II }\end{array}$} \\
\cline { 2 - 5 } & $\begin{array}{l}\text { Jumlah } \\
\text { Peserta }\end{array}$ & $\begin{array}{c}\text { Persen- } \\
\text { tase }\end{array}$ & $\begin{array}{c}\text { Jumlah } \\
\text { Peserta }\end{array}$ & $\begin{array}{c}\text { Persen- } \\
\text { tase }\end{array}$ \\
\hline $\begin{array}{l}\text { Sangat Tinggi } \\
(80-100 \%)\end{array}$ & 4 & 50 & 2 & 25 \\
$\begin{array}{l}\text { Tinggi } \\
(70-79 \%)\end{array}$ & 1 & 12,5 & 3 & 37,5 \\
$\begin{array}{l}\text { Sedang } \\
(60-69 \%)\end{array}$ & 3 & 37,5 & 3 & 37,5 \\
$\begin{array}{l}\text { Kurang } \\
(0-59 \%)\end{array}$ & 0 & 0 & 0 & 0 \\
\hline \multicolumn{1}{c}{ Jumlah } & 8 & 100 & 8 & 100 \\
\hline
\end{tabular}

Hasil pengamatan pada siklus II, pertemuan kedua menunjukkan bahwa masih ada peserta workshop yang mengalami kesulitan dalam mengemukakan pendapat, mengemukakan permasalahan tidak tepat, dan jika menjawab belum tentu benar. Berdasarkan tabel 3, hasil motivasi dan aktivitas peserta yang mencapai $70 \%$ belum memenuhi target sebanyak $85 \%$, hanya $62,5 \%$. Mengingat tujuan penelitian belum berhasil, maka perlu dilanjutkan dengan siklus ketiga.

\section{Siklus ketiga}

Pelaksanaan pada siklus ketiga sesuai dengan rencana penyajian. Pada tahap pelaksanaan, tindakan pada pertemuan pertama dilakukan workshop dan pembimbingan PTK pada kegiatan MGMP serta melalui program pendampingan melalui supervisi akademis. Tindakan pada pertemuan kedua berupa presentasi laporan hasil penelitian.

Pada tahap pengamatan (observasi), Hasil pengamatan pada siklus III, pertemuan pertama menunjukkan bahwa peserta workshop belum terbiasa berani bertanya atau mengemukakan pendapat, jika diberi stimulan responnya masih rendah, peserta workshop yang mengemukakan permasalahan belum tepat, kebenaran hasil yang diperoleh belum tentu benar. Terlihat dari persentase perolehan nilai yang penulis kriteriakan seperti tertera pada tabel 4 berikut.

Tabel 4. Hasil Motivasi dan Aktivitas Peserta workshop Pertemuan 1 dan 2 Siklus III

\begin{tabular}{lcccc}
\hline \multicolumn{1}{c}{ Kriteria } & \multicolumn{2}{c}{$\begin{array}{c}\text { Pertemuan 1 } \\
\text { Siklus III }\end{array}$} & \multicolumn{2}{c}{$\begin{array}{c}\text { Pertemuan 2 } \\
\text { Siklus III }\end{array}$} \\
\cline { 2 - 5 } & $\begin{array}{l}\text { Jumlah } \\
\text { Peserta }\end{array}$ & $\begin{array}{c}\text { Persen- } \\
\text { tase }\end{array}$ & $\begin{array}{c}\text { Jumlah } \\
\text { Peserta }\end{array}$ & $\begin{array}{c}\text { Persen- } \\
\text { tase }\end{array}$ \\
\hline $\begin{array}{l}\text { Sangat Tinggi } \\
(80-100 \%)\end{array}$ & 2 & 25 & 2 & 25 \\
$\begin{array}{l}\text { Tinggi } \\
(70-79 \%)\end{array}$ & 4 & 50 & 5 & 62,5 \\
$\begin{array}{l}\text { Sedang } \\
(60-69 \%)\end{array}$ & 2 & 25 & 1 & 12,5 \\
$\begin{array}{l}\text { Kurang } \\
(0-59 \%)\end{array}$ & 0 & 0 & 0 & 0 \\
\hline \multicolumn{1}{c}{ Jumlah } & 8 & 100 & 8 & 100 \\
\hline
\end{tabular}

Hasil pengamatan pada siklus III, pertemuan kedua menunjukkan bahwa motivasi dan aktivitas peserta dengan kriteria tinggi semakin meningkat yaitu mencapai $62,50 \%$. Bahkan sudah ada peserta yang motivasi dan aktivitasnya sangat tinggi yaitu mencapai $25 \%$. Walaupun masih ada peserta yang motivasi dan aktivitasnya sedang yaitu sebesar $12,50 \%$. Jadi total peserta yang sudah mencapai $70 \%$ sebanyak $87,5 \%$, sehingga target dari penelitian ini sudah dinyatakan memenuhi indikator keberhasilan.

Dalam penelitian ini, nilai pra siklus menggunakan nilai hasil tes awal, sebelum workshop peserta diberi soal tes awal. Langkah selanjutnya peserta diberikan sosialisasi PTK dan 
Tabel 5. Hasil ketuntasan peserta workshop setelah siklus I, II dan III

\begin{tabular}{lcccccc}
\hline \multicolumn{1}{c}{ Kriteria } & \multicolumn{2}{c}{ Siklus I } & \multicolumn{2}{c}{ Siklus II } & \multicolumn{2}{c}{ Siklus III } \\
\cline { 2 - 6 } & $\begin{array}{l}\text { Jumlah } \\
\text { Peserta }\end{array}$ & Persentase & $\begin{array}{l}\text { Jumlah } \\
\text { Peserta }\end{array}$ & Persentase & $\begin{array}{l}\text { Jumlah } \\
\text { Peserta }\end{array}$ & Persentase \\
\hline $\begin{array}{l}\text { Tuntas Perorangan, jika } \\
\text { mencapai nilai KKM (61) }\end{array}$ & 6 & 75 & 6 & 100 & 6 & 100 \\
\hline $\begin{array}{l}\text { Belum tuntas Perorangan, } \\
\text { jika belum mencapai nilai } \\
\text { KKM (61) }\end{array}$ & 2 & 25 & 2 orang tdk ada hasil & 2 orang tdk ada hasil \\
\hline $\begin{array}{l}\text { Tuntas klasikal, jika 85\% } \\
\text { jumlah peserta } \text { workshop } \\
\text { memperoleh nilai } \geq \text { KKM }\end{array}$ & $\begin{array}{c}\text { Secara klasikal belum } \\
\text { tuntas perlu remidi }\end{array}$ & tuntas klasikal & tuntas klasikal \\
\hline
\end{tabular}

diberi pendampingan supervisi akademis dalam kegiatan MGMP. Pada akhir siklus kesatu, kedua, dan ketiga, peserta workshop diberi tes akhir selama kurang lebih 15 menit. Dari hasil analisis diperoleh rekapitulasi hasil tes akhir pada akhir siklus kesatu, kedua dan ketiga disajikan dalam tabel 5.

Berdasarkan tabel 5 (lima) dapat dideskripsikan bahwa peserta workshop dapat mencapai ketuntasan perorangan 100\% pada siklus kedua dan ketiga. Siklus kedua dan ketiga semua peserta memperoleh nilai melebihi KKM. Terdapat 2 (dua) peserta pada siklus kedua dan ketiga tidak mengumpulkan tugas karena suatu tugas dinas yang tidak bisa ditinggalkan. Dalam penelitian ini jumlah subjek penelitian tereksklusi sehingga ditetapkan hanya ada 6 (enam) peserta yang mengumpulkan tugas dengan hasil semua melebihi KKM. Artinya tercapai ketuntasan klasikal bagi peserta workshop.

Dilihat dari tingkat penguasaan materi, diperoleh data hasil penelitian seperti pada tabel 6 berikut.

Tabel 6. Rata-rata nilai penguasaan materi peserta workshop

\begin{tabular}{ccccc}
\hline $\begin{array}{c}\text { Identitas } \\
\text { Peserta }\end{array}$ & $\begin{array}{c}\text { Pra } \\
\text { Siklus }\end{array}$ & $\begin{array}{c}\text { Siklus } \\
\text { I }\end{array}$ & $\begin{array}{c}\text { Siklus } \\
\text { II }\end{array}$ & $\begin{array}{c}\text { Siklus } \\
\text { III }\end{array}$ \\
\hline A & 60 & 80 & 85 & 86 \\
B & 55 & 75 & - & - \\
C & 70 & 96 & 97 & 98 \\
D & 50 & 60 & 75 & 87 \\
E & 30 & 60 & 65 & 90 \\
F & 60 & 91 & 92 & 93 \\
G & 65 & 75 & 80 & 90 \\
H & 40 & 75 & - & - \\
\hline Rata- & 53,75 & 76,50 & 82,33 & 90,67 \\
rata &
\end{tabular}

Dari tabel 6 dapat dideskripsikan bahwa penguasaan materi peserta dari pra siklus ke siklus berikutnya mengalami kenaikan. Tingkat penguasaan materi rata-rata dari 53,75 meningkat secara bertahap sampai 90,67.

Berdasarkan dari hasil penelitian menunjukkan bahwa pengetahuan guru tentang pengembangan profesi semakin meningkat setelah peserta diberi workshop, hal ini didukung oleh hasil penelitian Wahyudi yang menyimpulkan bahwa workshop dan pendampingan dapat meningkatkan secara signifikan terhadap pemahaman dan keterampilan PTK dalam Pengembangan PKB bagi Guru Sekolah (Wahyudi, 2018: 98).

Dari hasil penelitian juga menunjukkan bahwa pembimbingan dalam kegiatan PKB berdampak pada peningkatan motivasi guru untuk melakukan PTK, yang didukung oleh hasil penelitian dari Subakdi bahwa keterampilan guru SMP kelas VIII di SMP binaan kabupaten Sragen Semester I tahun pelajaran 2017/2018 dalam menyusun PTK dapat ditingkatkan melalui pembimbingan (Subakdi, 2018: 84).

Hasil penelitian juga menunjukkan bahwa dengan adanya pembimbingan guru memahami tentang karakteristik PTK, Prinsip PTK, prosedur melaksanakan PTK. Sehingga guru termotivasi untuk mengembangkan profesinya dengan cara melaksanakan PTK. Hasil tersebut sesuai dengan hasil penelitian yang dilakukan oleh Fitria yang menyatakan bahwa pelatihan dapat menumbuhkan motivasi dalam menyusun dan melaksanakan PTK, disamping itu pelatihan juga dapat meningkatkan kinerja sekolah melalui peningkatan profesionalisme guru (Fitria, 2018: 23).

Hasil penelitian menunjukkan bahwa, melalui pendampingan dapat meningkatkan aktivitas menulis. Hasil penelitian yang mendukung kesimpulan penelitian ini adalah hasil penelitian Beni Setiawan yang menyimpulkan bahwa Pendampingan Penulisan 
Karya Tulis Ilmiah melalui MGMP IPA Kota Probolinggo dapat membuat guru-guru IPA membuat hasil laporan PTK (Beni Setiawan, 2015: 76).

Hasil penelitian menunjukkan bahwa dengan memotivasi guru untuk mengembangkan profesi melalui kegiatan penelitian berarti guru akan mencari akar masalah dari pembelajarannya di kelas kemudian mencari jawaban dari kajian pustaka. Membuat proposal penelitian dan melaksanakan PTK kemudian menulisnya dalam bentuk laporan hasil Selanjutnya mengusulkannya ke tim penilai angka kredit sampai memperoleh nilai yang dibutuhkan yang akhirnya akan meningkatkan golongan dan ruang kepangkatannya artinya profesionalisme guru meningkat. Dengan guru melaksanakan PTK berarti kualitas pembelajaran dan hasil belajar siswa meningkat. Hal ini sesuai dengan hasil penelitian Somatanaya bahwa kegiatan pelatihan dapat membantu guru dalam membuat laporan PTK yang berkualitas (Somatanaya, 2017: 174).

Disamping itu hasil penelitian menunjukkan bahwa setelah dilakukan tindakan dan perbaikan, diperoleh nilai rata-rata tes peserta workshop setelah siklus kedua lebih dari nilai rata-rata tes peserta workshop setelah siklus pertama dan melebihi nilai rata-rata tes peserta workshop sebelum siklus pertama.

\section{Simpulan dan Saran}

Melalui Kegiatan workshop penulisan PTK dapat meningkatkan motivasi guru dalam melaksanakan PTK sehingga profesi guru meningkat. Workshop dan pembimbingan dapat meningkatkan pengetahuan guru tentang pengembangan profesi; meningkatkan motivasi guru untuk melakukan kegiatan pengembangan profesi; meningkatkan motivasi guru untuk menulis PTK; meningkatkan aktivitas menulis bagi peserta workshop dan dapat meningkatkan profesionalisme guru.

Sebaiknya pihak yang berwenang menfasilitisai pelaksanaan workshop secara lebih intensif, agar para guru lebih kompeten dan lebih professional sehingga guru bisa menemukan sendiri permasalahan yang dihadapi di kelas dan menemukan solusi permasalahan tersebut. Sebagai hasilnya guru mampu melaksanakan pembelajaran seperti yang diamanahkan oleh standar proses, akibatnya peserta didik bisa menikmati pembelajaran dengan nyaman yang endingnya prestasi belajar peserta didik dapat meningkat. Disamping itu pemeritah juga perlu mempermudah prosedur pengusulan angka kredit agar tidak ada kendala dalam kenaikan pangkat guru.

\section{Daftar Pustaka}

Agus Purnama. (2015). Peningkatan Kemampuan Melakukan PTK melalui Workshop Guru bahasa Inggris di Bantul. Jurnal Telkomdik Vol. VIII no. 9.

Balai Dikmen KP. (2020). Data Kenaikan Pangkat Guru Tahun 2020.

Beni Setiawan, dkk. (2015). Pendampingan Penulisan Karya Tulis Ilmiah pada Media Wapik bagi Guru-Guru IPA Melalui MGMP IPA Kota Probolinggo. Jurnal Abdi, 1(1), 71 77.

Dinisiswani dan Suharno. (2016). PTK dengan Pembelajaran Berbasis Kearifan Lokal dan Penulisan Artikel Ilmiah. Jurnal Ilmiah Pendidikan, 9(2).

Fitria, dkk. (2018). Upaya Meningkatkan Profesionalisme Guru melalui pelatihan PTK di SMK M 1 Bantul. Jurnal Elinvo, 3(2).

Madzuki dan Kholid, M. N. (2017). Pengembangan Kemampuan Penelitian dan Penulisan Karya Ilmiah bagi Guru Matematika SMA/SMK Muhammadiyah di Klaten dan Sukoharjo.

Martinis Yamin. (2006). Sertifikasi Profesi Keguruan di Indonesia. Jakarta: Gaung Persada Press.

Mustofa. (2007). Upaya pengembangan Profesionalisme Guru di Indonesia. Jurnal Ekonomi dan Pendidikan. 4(1).

I Gede Astawan, dkk. (2019). Pelatihan Penulisan Karya Ilmiah Bagi Guru-Guru SD Gugus VII Kecamatan Sukasada, Kabupaten Buleleng. International Journal of Community Service Learning, 3(3), 116-121. https://ejournal.undiksha.ac.id/index.php/ IJCSL

Padrul Jana dan Bayu Pamungkas. (2018). Pelatihan PTK bagi Guru SD Negeri Guwosari. Jurnal Abdimas Dewantara, 1(1).

Sujarwo. (2020). Strategi Pembelajaran Orang Dewasa (Pendekatan Andragogi). From http://staff.uny.ac.id/sites/default/files/pe nelitian/Dr.\%20Sujarwo,\%20M.Pd./Makala h-

Strategi\%20Pembelajaran\%200rang\%20de wasa\%20(Repaired).pdf

Somatanaya, dkk. (2017). Pelatihan PTK bagi Peningkatan Karier Guru SD di Kota Tasik Malaya. Jurnal Pengabdian Masyarakat, Jurnal Siliwangi, 3(1). 